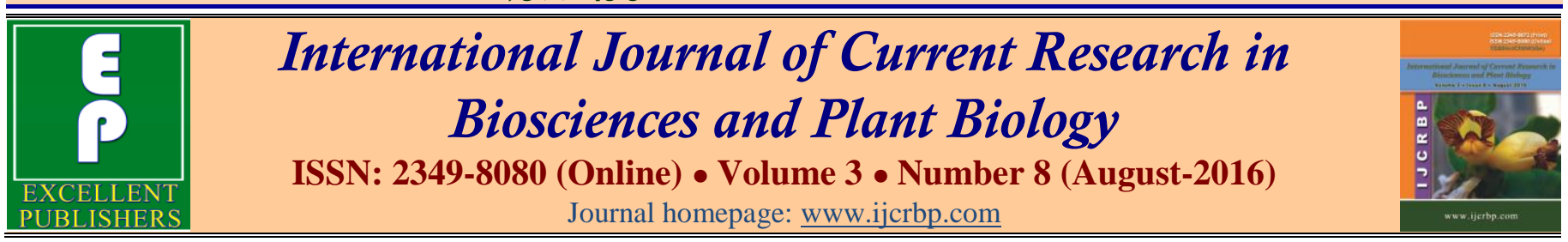

Original Research Article

doi: http://dx.doi.org/10.20546/ijerbp.2016.308.007

\title{
The Conservation and Management Challenges of the Rainforest of Idenau in Mount Cameroon National Park, Southwest Region, Cameroon
}

\author{
Melle Ekane Maurice*, Nkwatoh Athanasuis Fuashi, Terence Njopin Hele and \\ Achiri Akere Bell
}

Department of Environmental Science, Faculty of Science, University of Buea P.O. Box 63, Republic of Cameroon

*Corresponding author.

\begin{abstract}
A bstract
Population growth has become a major force behind contemporary environmental degradation in many rural and urban environments. Based on this perspective, this survey examines the impact of human population growth on the forest ecosystem with specific reference to human impact on forest resource exploitation in Idenau, South-west region, Cameroon. Data collection was done by questionnaire administration. The questionnaire administration process witnessed an oral interview to the respondents targeted for the survey. The questionnaires were given to all the respondents and collected some days later. The collected data was analysed by using chi-square and correlation statistical models. The study shows a correlation $\left(\mathrm{r}^{2}=0.092\right.$ at $\left.p<0.05\right)$ between crop cultivation and the human population increase. The survey has also shown a significant correlation relation $\left(\mathrm{r}^{2}=0.957\right.$ at $\left.p<0.05\right)$ between the conservation awareness and fuel-wood usage at homes in the study area. Moreso, the study has shown a correlation between fuel-wood usage and extreme weather changes $\left(\mathrm{r}^{2}=0.668\right.$ at $p<0.05)$. The participation of the local inhabitants of Idenau in climate change mitigation and occupation correlated $\left(\mathrm{r}^{2}=0.868\right.$ at $\left.p<0.05\right)$ significantly as well. Furthermore, the study has recorded a correlation $\left(\mathrm{r}^{2}=0.620\right.$ at $\left.p<0.05\right)$ between gender and agricultural practices. This survey revealed that poverty, lack of awareness on environmental education, human population increase, and unemployment of the youth have pushed the people of Idenau into wildlife-hunting, gathering, and the farming of rainforest of mount Cameroon national park despite the conservation policy restrictions.
\end{abstract}

\author{
Article Info \\ Accepted: 14 July 2016 \\ Available Online: 06 August 2016
}

Keywords

Conservation

Environment

Forest ecosystem

Rainforest

Wildlife

\section{Introduction}

The equality of environment is constantly losing its status due to increase in population growth in most countries of world. Today, the clean natural atmospheric air has been populated with dangerous gases and particulate, the soil fertility is reducing and water bodies have been greatly polluted by human activities which cause the environment to lose it natural balance. According to Collins (1984), pollution has become a major factor that has cause environmental degradation in terms of reducing the quality of the environment. According to him environmental degradation is a situation where the environment loses its natural equilibrium. Banuri and Apffel-Marglin (1993), affirm that population has been a chief agent of environmental degradation in most cities of the world. He further explained that man main occupations were hunting and gathering of fruits but later as human population increased, man invented new techniques which have 
constituted great menace to the natural environment. Bryant et al. (1997) stated that as population continue to increase it will become more difficult to limit the environmental degradation that accompanies it. In Idenau, it is obvious fact that population grows at geometrical rate while food production grows at arithmetical rate according to Bryant et al. (1997).

The situation of anthropogenic activities in Idenau, South-west region, Cameroon has not only degraded the forest ecosystem but has caused the environment to lose its natural equilibrium at the same time has exerted more pressure on the natural resources. Beside, population growth in these communities have led to increasing environmental problems such as loss of plant and animal species, pollution, soil infertility among others. To this end, one may ask if anthropogenic pressure on the forest ecosystem can be ever controlled in Idenau, South- west and Cameroun as a whole. How can the people extract these resources without degrading the environment? Therefore, this curriculum tends to critically examine the impact of population growth on forest degradation with specific reference to impact of population growth on forest resources depletion, major resources, methods resource of forest extraction and the impact of forest resource exploitation in the area. The conservation of tropical rain-forests has received tremendous and exceptional publicity over the recent years. Almost everyone have seen or heard something about disappearing rainforests, the resulting effects and what they should do or shouldn't do to remedy the situation. The reason on working on this curriculum vitae is to improve the understanding of people concerning rainforests, their importance i.e., the ecosystem services they render such as carbon sequestration, climate change mitigation, their importance in the hydrological cycle, nutrient cycling, and biogeochemical cycles, and also there importance as a source of natural capital. It is also aimed at helping populations and individuals acquire awareness and sensitivity towards the tropical rainforests, and the environment as a whole, issues, and problems related to developments. It can also help individuals groups and society acquire a set of values and feelings of concern for the environment and actively participate in the protection of the environment. However, FAO does not consider tree plantations that provide non-timber products to be forest although they do classify rubber plantations as forest. Forest degradation occurs when the ecosystem functions of the forest are degraded but where the area remains forested rather cleared (Bryant et al., 1997). Thirty per cent of the earth's land area or about 3.9 billion hectares is covered by forests. It was estimated that the original forest cover was approximately six billion hectares in the past (Bryant et al., 1997).

The Russian Federation, Brazil, Canada, the United States of America and China were the most forest rich countries accounting to 53 percent of the total forest area of the globe. Another 64 countries having a combined population of two billions was reported to have forest on less than ten percent of their total land area and unfortunately ten of these countries have no forest at all (FAO 2001a). Among these countries 16 are such which had relatively substantial forest areas of more 1 than one million hectares each and three of these countries namely Chad, the Islamic Republic of Iran and Mongolia each had more than ten million hectares of forest (FAO 2001a). The forest area remained fairly stable in North and Central America while it expanded in Europe during the past decade. Asian continent especially in India and China due to their large scale afforestation program in the last decade registered a net gain in forest area. Conversely the South America, Africa and Oceania had registered the net annual loss of forest area (FAO 2001a).

Most of the world's forests are in open landscapes with no restrictions on use as only around 8 to 12 percent of the world tropical forests are in parks and reserves (FAO 2001a). In its Forest Resources Assessment 2000 referred to above, FAO estimated that the world forests cover by 1999 had been reduced from 6000 million hectares in the 1850 s to 3500 million hectares (FAO 2001a). This loss is attributed to human exploitation, and most of this clearance occurred in the latter half of the twentieth century (FAO 2001a). The global distribution of deforestation is such that it is generally more serious in developing countries of Latin America, Asia and Africa than in the developed world. FAO concluded in its report that the net loss of forests had slowed down by 20 percent during the 1990s decade as compared to the 1980s. However, this conclusion has been questioned by other sources. For example, the World Resources Institute (WRI) argued that deforestation rates increased in tropical Africa and other parts of the Third World countries during the 1990 decade. Together with the World Wide fund for Nature (WWF), WRI is critical of FAO's definition of forests which include plantations.

According to FAO (2001b), a forest is vegetation with a minimum of 10 percent crown cover and this includes both natural forests as well as plantations. But WRI and WWF contend that this definition is misleading because when plantations are excluded, the rate of natural forest 
loss is higher during the 1990s than the previous decade, particularly in the tropics. This debate about deforestation rates highlights the contested nature of environmental issues and the significance of who tells the story or produces the knowledge about it.

\section{Materials and methods}

\section{Description of study area}

Idenau is the head quarters of west coast sub division located in Fako division of the Southwest Region of
Cameroon (Fig.1; Melle and Nakogho, 2015). It is located about $29 \mathrm{~km}$ from Limbe. The Idenau municipality has an estimated population of about 30,000 inhabitants living in 8 villages among which are fishing ports, native communities and Cameroon Development Cooperation camps. It is located between latitude $4^{\circ} 23^{\prime}-5^{\circ} 33 \mathrm{~W}$ and $7^{\circ} 33^{\prime}-24 \mathrm{E}$ and longitude $5^{\circ} 70^{\prime} \mathrm{N}$ and $7^{\circ} 24 \mathrm{~S}$ with an altitude of about $300 \mathrm{~m}$ above sea level in the main land area and $5 \mathrm{~m}$ in the maritime area (Tako-Tanyi, 1999), Sustainable Wildlife Management, West Coast Area of Mount Cameroon, Project Limbe.

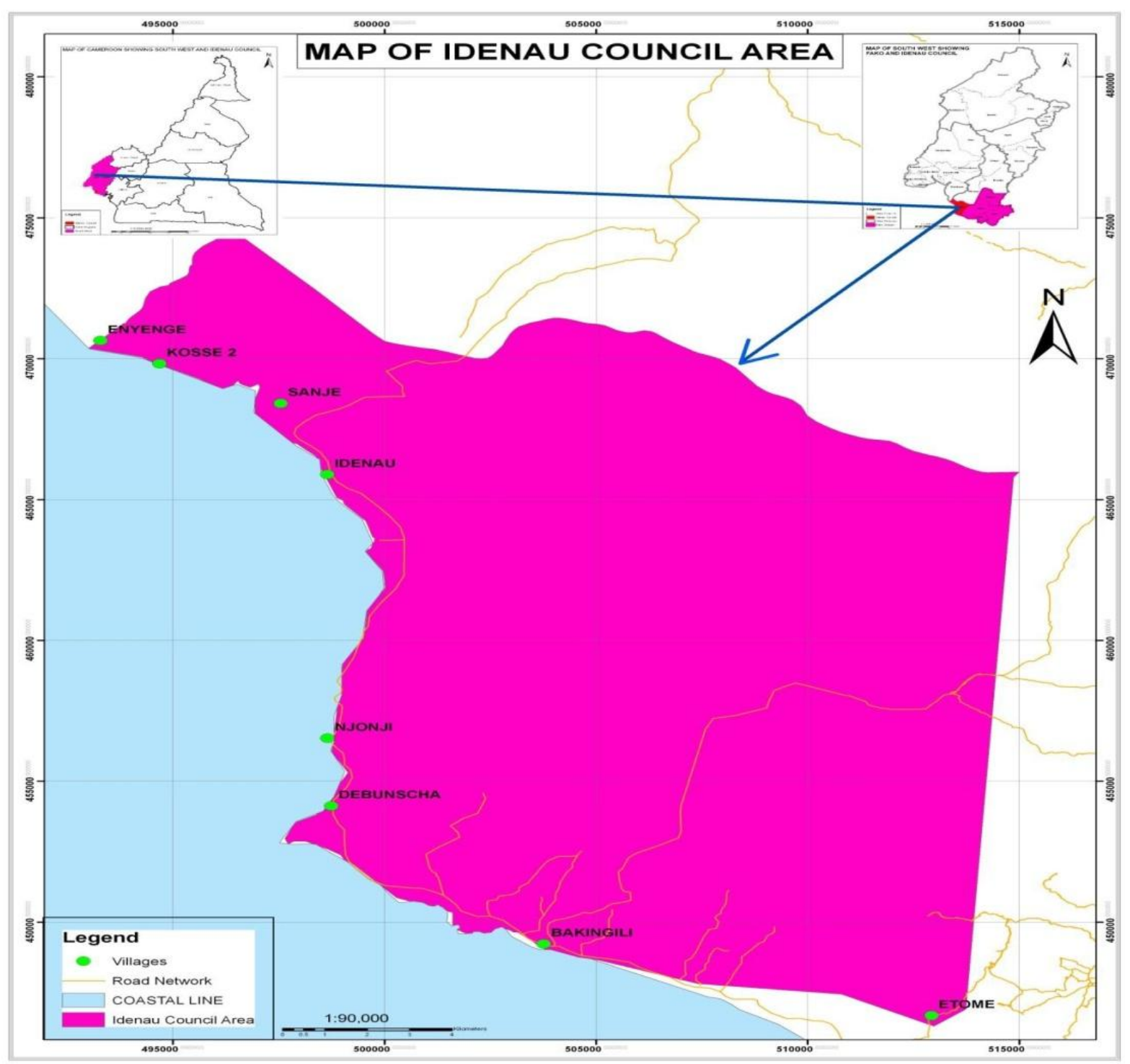

Fig. 1: Map of Idenau Sub-Division (Source: Melle and Nakogho (2015).

Generally, Idenau municipality is found on the North of Atlantic Ocean and the windward side of mount Cameroon. It is bounded to the north by a stretch of mount Cameroon national park to the east by Limbe municipality, to the south by the Atlantic Ocean, and to the West by Bamusso sub division. Average temperature 
range is about $25-30^{\circ} \mathrm{C}$ of about $5000 \mathrm{~mm}$ to $8000 \mathrm{~mm}$. Idenau has an equatorial climate that is marked by 2 distinct seasons (dry and rainy season). Rainfall spreads from match to November with a temperature range of about $25-28^{\circ} \mathrm{C}$. The rainfall peaks in July, August and September (Melle and Nakogho, 2015). The peak of the dry season falls in December and January.

The mean annual relative humidity ranges between $80 \%$ and $95 \%$. These climatic conditions make the soil favorable for the cultivation of oil-palms, Cocoa, cassava, and other food crops. The west coast is a distinct area with respect to rainfall. Debundcha is noted to have the highest rainfall in Africa, and its rainfall is observed throughout the year. The dry season is characterized by dry winds that blow from the mountain in the northeast to the southern direction. During the period, daily temperatures are high with a slight drop in the night. During the rainy season, rains are heavy creating a favorable environment for agricultural cultivation (Melle and Nakogho, 2015). These rains are occasionally associated with storms and floods that are destructive to crops and property.

The dominant soil type in the municipality is the dark fertile and stony volcanic soils with patches of alluvial and sandy loam soils. The hills are a dissected plateau of old volcanic rocks with a few sedimentary belts. These soil types couple with the level terrain is very good for agriculture generally and plantain agriculture in particular (Asong, 2001).

\section{Data collection}

Different classes of people with different occupations were being interviewed to get their knowledge on forest policies and management strategies. But the targeted population for this interview was the forest exploiters. This is because they are concerned with the objectives of the project. Also the local authorities like the quarter heads, chiefs and council authorities also gave detail and vital information need for this study. The questionnaires were randomly administered to the target population in the study area (Marshal, 1996). Each household at least one adult individual was interviewed and given a questionnaire. The number of male respondents was higher than the number of female respondents due to the fact that males showed more readiness in filling these questionnaires. A total number of three hundred questionnaires given out to the respondents were all collected fully answered. The data analysis was done by the use of correlation and chi-square statistical models.

\section{Results}

There is a positive significant correlation $\left(\chi^{2}=0.923\right.$ at $p<0.05)$ between fuel-wood usage and the human population of Idenau (Table 1). Due to severe shortage of cooking domestic gas supplies, high rate of unemployment and easy accessibility and availability of fuel-wood has made most occupants of the area employ the use of fuel-wood for domestic activities such as cooking. The human population in this area is poor and highly unemployed, the reason which the forest gathering has no option. The study has also shown (Table 2) a significant correlation $\left(\chi^{2}=0.668\right.$ at $\left.p<0.05\right)$ between the gathering of fuel-wood and weather challenges. The study area is known to experience extreme weather conditions, heavy and frequent rainfall. Before the raining season sets in, most individuals in the study area gather and store fuel-wood because during the peak of rainy seasons the forest becomes inaccessible due flooding. A correlation exists between (Fig. 2) the peoples occupation and their participation in management programmes $\left(\mathrm{r}^{2}=0.868\right.$ at $\left.p<0.05\right)$. The major activity carried out in the study area is agriculture for subsistence. The rate of change in climate in this place has been experienced and if agricultural practices are not sustainable enough to reduce rate of deforestation, climate change might be experienced more in the near future. The worst set-back to sustainable forest management is the lack of conservation education. Furthermore, there is a correlation (Fig. 3) between gender and agricultural practices $\left(r^{2}=0.620\right.$ at $\left.p<0.05\right)$.

Table 1. Fuel-wood usage and human population in Idenau.

\begin{tabular}{llll}
\hline Chi-Square Tests & Value & df & $\begin{array}{l}\text { Asymp. Sig. } \\
\text { (2-sided) }\end{array}$ \\
\hline Pearson Chi-Square & $0.164^{\mathrm{a}}$ & 2 & 0.921 \\
Likelihood Ratio & 0.296 & 2 & 0.862 \\
$\begin{array}{l}\text { Linear-by-Linear } \\
\text { Association }\end{array}$ & 0.001 & 1 & 0.977 \\
No. of Valid Cases & 293 & & \\
\hline
\end{tabular}

a. 3 cells $(50.0 \%)$ have expected count less than 5 . The minimum expected count is 0.13 .

Table 2. Fuel-wood gathering and extreme weather changes.

\begin{tabular}{llll}
\hline Chi-Square Tests & Value & df & $\begin{array}{l}\text { Asymp. Sig. } \\
\text { (2-sided) }\end{array}$ \\
\hline $\begin{array}{l}\text { Pearson Chi-Square } \\
\text { Likelihood Ratio }\end{array}$ & $11.271^{\mathrm{a}}$ & 2 & 0.004 \\
$\begin{array}{l}\text { Linear-by-Linear } \\
\text { Association }\end{array}$ & 0.527 & 2 & 0.023 \\
$\begin{array}{l}\text { No. of Valid Cases } \\
\text { a. 3 cells (50.0\%) have expected count less than 5. The } \\
\text { minimum expected count is } 0.10 .\end{array}$ & 1 & 0.667 \\
\end{tabular}




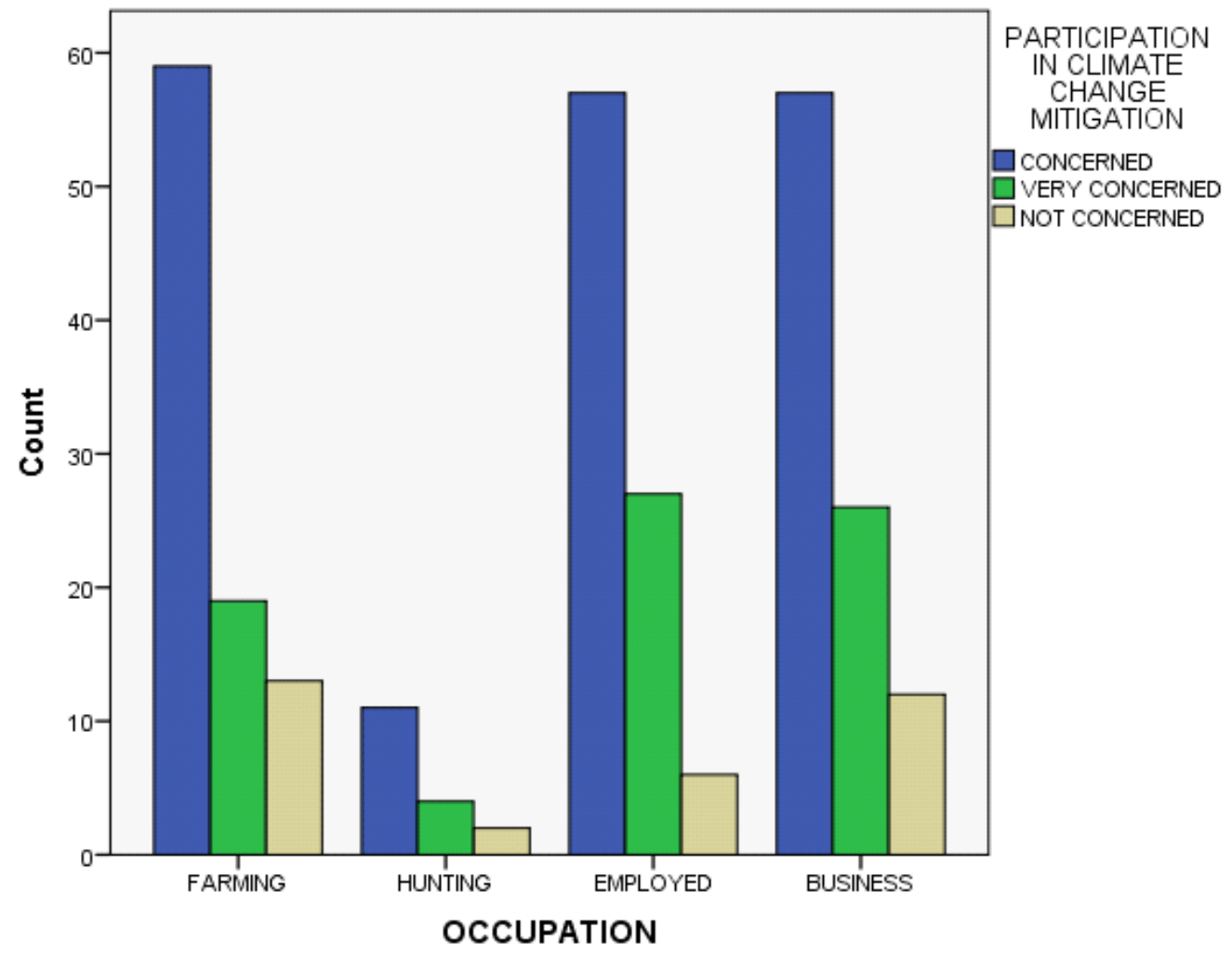

Fig. 2: The participation in climate change mitigation and occupation.

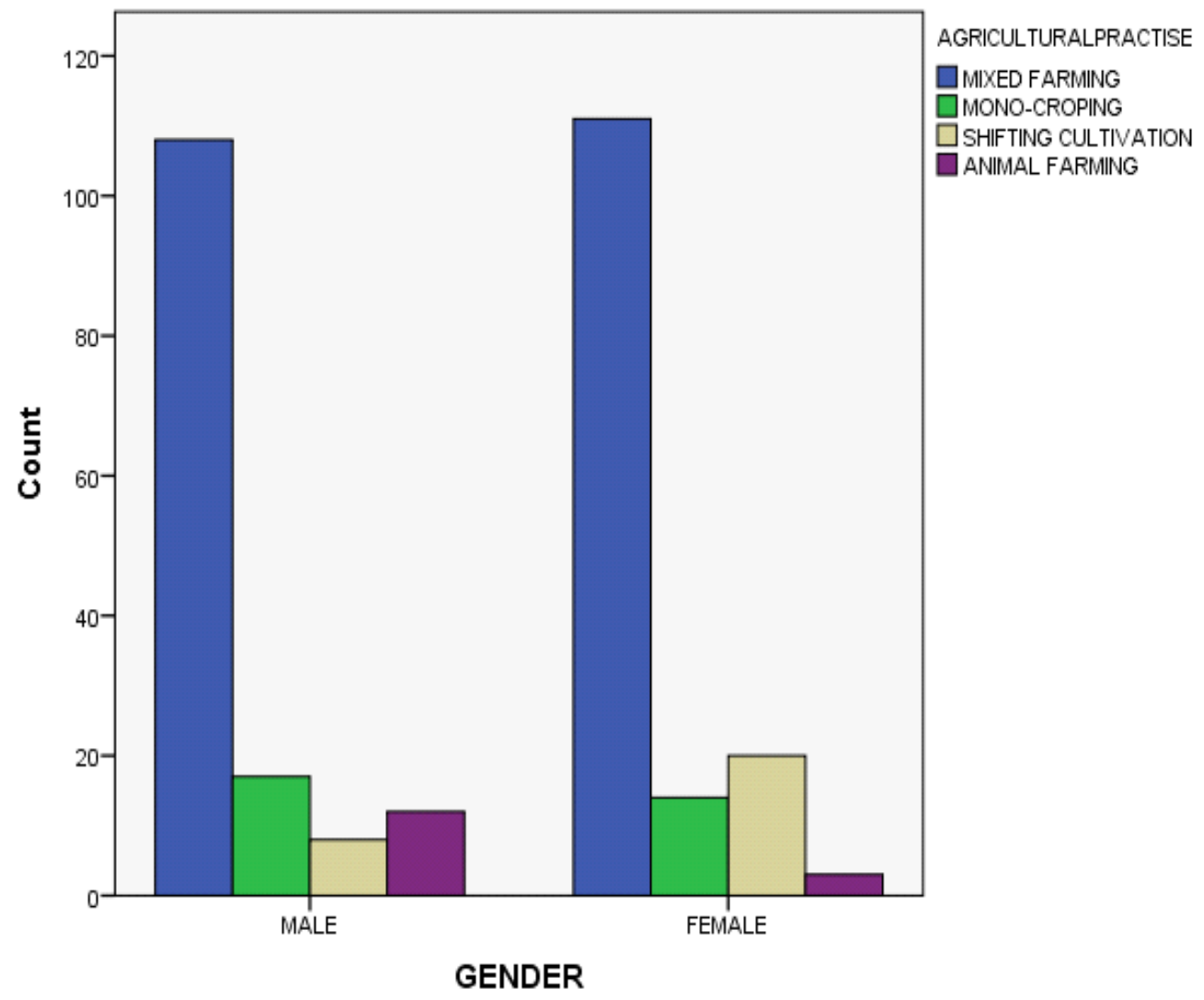

Fig. 3: gender and agricultural practice. 


\section{Discussion}

The increase in human population in Idenau is mainly due to the local sea fishing. Hence, the fish preservation for market exportation is done by smoking. For this reason the fuel-wood gathering and harvesting from the wild is intensive. Also, as the human population size is increasing, there is need for conservation awareness (Fig. 3) in the area. Seminars and workshops could be planned and held as to educate the occupants on the corresponding effects of indiscriminate deforestation. Generally, human population growth has been a major force behind contemporary environmental degradation in many rural and urban environments (Atte, 1994). A direct cause of deforestation on this landscape is generally the conversion of forests into some other forms of land uses; these include agriculture, particularly shifting cultivation, and over-exploitation of forest products for industrial or domestic use, such as lumbering and charcoal processing (Table 2). Ecologically, the rainforest serves as sinks via playing vital role in carbon sequestration, absorbing inorganic sources of carbon, such as carbon-dioxide and converting it into less harmful forms via cellular processes through photosynthesis. Deforestation does not only result to the disturbance of ecological processes, such as, hydrological cycle, and biogeochemical cycles, but also leads to reduction in biodiversity and loss of species (Atte, 1994).

Agriculture remains the backbone of Cameroon economy from time immemorial. The presidential speech of $10^{\text {th }}$ February 2016 encouraged all Cameroonians that the soil does not fail. Mount Cameroon rainforest has been under pressure from agricultural expansion. The encroachment into the rainforest has resulted in many rural indigenous people taking farming as their major activity. The exhaustion of the soil, failure of crop yield to maximum capacity has forced many people to acquire more farmlands to survive losses of bad harvest stemming from recent environmental deterioration. In addition the slash and burn shifting cultivation system of farming, practiced by the local people along this forest margins is very destructive to nature (Fig. 3). Continuous deforestation here for agriculture has led to habitat loss greatly and forest fragmentation which is an important cause of reduction in species populations and increase species extinction rates. Among, different tree species found in this rainforest, are African Cherry (Prunus africana), the most endangered (Forlemu, 2013). Prunus africana represents the fourth most popularly used medicinal plant species that is collected by $80 \%$ of households in Mt. Cameroon region (Ekane, 2000). Locally, it is a huge source of income resource to many families and it is also used by traditional healers for the treatment of chest-pain, malaria, headache, body-allergies, and kidney diseases. Myers (1994) observed that about $60 \%$ of the destruction of tropical moist forests is for agricultural purposes. Tropical forest is one of the last frontiers in the search for subsistence land for the most vulnerable people worldwide (Myers, 1992).

Afforestation could be encouraged so as to increase availability of trees for timber exploitation. There has been some success in devising schemes (Fig. 2) to collect payments for environmental services like carbon sequestration, biodiversity conservation, catchment protection and ecotourism (Bokwe, 2014). This success can further be more realized by integrating participatory mode of management with these collection schemes to ensure rights and tenure with equity in resource and benefit sharing for improving the livelihood of the rural poor who actually are the primary stakeholders of conservation and management. A transparent government is essential to slow down the rate of deforestation. Environmental NGOs contributing towards conservation management programmes has been working enormous. They are better equipped to avoid corruption and are very effective at getting to the people at the frontier of need (Bokwe, 2014).

Hunting is another reason why people encroach into the rainforest within this community. This is mostly done by the indigenous population living along the forest margins and some strangers who have come in with the culture of hunting. Despite the laws put in place to protect wildlife from the hands of the hunters, the wildlife population is still declining alarmingly from the protected forest. A lot of households still keep dogs today just for the hunting of wildlife in the forest of mount Cameroon. Forlemu (2013), observed that the main threats to biodiversity in this area are linked to hunting, carried out by means of wire-snares and locally manufactured guns. Bush-meat is sold fresh or smoked in Fako towns and many other parts of Cameroon. He noted that two classes of hunters, otherwise known as wildlife collectors operate in Mt. Cameroon area, subsistent hunters for household feeding and commercial large scale hunters for income generation. Hunting has always been a major source of livelihood for the local villagers in Mt. Cameroon region. In the past, traditional hunting for domestic purposes posed very little threat to animal populations. However, between 1970 and1980 poaching of the African elephant for ivory increased 
drastically, this was worsened by the deliberate action of the Cameroon Development Cooperation (CDC) authorities in also killing elephants for the protection of their palm plantations (Forlemu, 2013).

The collection or gathering of non timber forest product is another reason why people have to encroach into this rainforest. Non timber forest products (NTFPs) are products of biological origin (plants, fungi and animals). The lucrative business of wild-eru has remained a major export crop from Idenau to neighbouring countries like Nigeria and Equatorial Guinea. This has forced many young people into the forest for its harvest. Logging for commercial purpose has remained one of the fundamental factors for income generation through which mankind depends on especially in the developing world due to poverty and population increase. Putz et al. (2001) noted that logging can seriously degrade forests habitat. The local population is poor due to unemployment, the reason for which they resort the rainforest exploitation for wood used for their house construction. Unfortunately, the wood harvesting from the forest is very unsustainable (Table 1), leading to a heavy environmental cost of degradation and depletion (Aplet et al., 1993).

Most of these individuals ascertain that woody buildings are cheaper and the materials are more accessible than modern blocks and concrete houses. Nevertheless, the perpetual existence of poverty and population increase in many forested areas in Cameroon translates an atmosphere of chaos in the management of conservation laws and policies. Apart from logging for commercial purpose and fuel wood collection, Indian-bamboo harvesting has also become a serious challenge. These bamboos are widely seen used in construction sites, especially when a storey building is being raised. The local construction companies use this bamboo to support the fresh construction flows (Aplet et al., 1993). Most local construction companies employment young men for the bamboo harvesting for their construction.

\section{Conclusion}

The unprecedented human population increase serves as the main driver to ecosystem and forest degradation in this eco-zone. As the population size increases and the financial resources become limited peoples are compelled to switch to forest resource gathering and exploitation. Population growth associated with the looming global land scarcity increases the complexity of future pathways of land use change. In a more interconnected world, agricultural intensification especially in the rural community is causing more cropland expansion in the developing world.

The rapid rate of deforestation has been attributed to various factors such as creation of land for settlements, high level of poverty (which causes occupants of forested areas to engage in indiscriminate forest exploitation), lack of knowledge on the consequences of deforestation, high level of unemployment and corruption in the national government (Bisong, 2001). This can be further addressed by community based forest management which builds on political goodwill and strong community institutions and also organizing workshops and seminars on educating the community on the benefits of sustainable foresting activities. Also, incentives, laws and policies could be drafted and enforced so as to mitigate deforestation activities (Barraclough and Ghimire, 1995). New challenges from climate change require urgent action to explore and protect the remaining forests which is the main source of livelihood of the local people. The enhancement of conservation activities will protect the forest ecosystem for future generational uses and mitigate climate change situation. Sustainable development practices, especially in the agricultural sector empower conservation programmes. The survey has revealed that effective rainforest management requires the involvement of the local people in the community (Banuri and ApffelMarglin, 1993).

Control of population size is important in reducing deforestation rate in developing countries. A rapidly increasing population size will require more infrastructures, more socio-economic amenities, more resources, food resources and so on. All these result in cutting down to make land available for construction and agricultural purposes. Also, increase in job availability will lead to a corresponding increase in rate of employment, which will reduce pressure on the remaining forests for new human settlement and land-use for local farming. The national government should initiate and sponsor reforestation and afforestation programmes. This strategy would not only reduce the harvesting of timber but also provides an alternative source for fuel-wood. We can stop using timber from the wild and urge others to do same, provided silvicultural tree-farming practices are made available. Laws, policies and legislations protecting the sustainable forest management practices should be such be encouraging to the local people and related institutions to participate in forest management and conservation programmes. 


\section{Conflict of interest statement}

Authors declare that they have no conflict of interest.

\section{References}

Aplet, G. H., Johnson, N., Oison, J.T., Sample, V.A., 1993. Defining Sustainable Forestry. Island Press, Washington DC. pp.34-45.

Asong, A., 2001. Forest degradation and forest reservation strategies in the South West Province. In: Culture and Environment (Eds.: Dunlop, J., Roy, W.). University of Strachdye/University of Buea. pp.23-30.

Atte, O. D., 1994. Land and Forest of Cross River State: A Participatory Appraisal of Rural People Perception and Preference. Working Paper, FDD/CRSEP. pp.3-9.

Banuri, T., Apffel-Marglin, F., 1993. A systems-ofknowledge: Analysis of deforestation, participation and management. In: Who Will Save the Forests? Knowledge, Power and Environmental Destruction (Eds.: Banuri, T., Marglin-Appffel, F.). The United Institute for Development Economic Research, UNU/WIDER, London, ZED Books. pp.1-23.

Barraclough, S.L., Ghimire, B.K., 1995. Forests and Livelihoods: The Social Dynamics of Deforestation in Developing Countries. Macmillan Press, London.

Bisong, F.E., 2001. Farming systems and forest biodiversity conservation towards a theory and model for sustainable natural resource management. In: Natural Resource Use and Conservation Systems for Sustainable Rural Development (Ed.: Bisong F.E.). Baaj International Company, Calabar. pp.162-176.

Bokwe, S.N., 2014. Adapting Forest Governance to Climate Change Mitigation and Poverty Alleviation; The Case of Forest Rserves in the Mount Cameroon Region. Unpublished Ph.D. thesis, Department of Geography, University of Buea. pp.56-78.
Bryant, D., Nielsen, D., Tangley, L., 1997. The Last Frontier Forests- Ecosystems and Economies on the Edge. World Resource Institute, Washington DC.

Collins, W., 1984. Collins Atlas of the World. Collins, London Glasgow.

Ekane, N. B., 2000. The Socio-economic Impact of Prunus africana Management in the Mount Cameroon Region; Case Study of the Bokwango Community. M.Sc. Thesis from the department of Urban Planning and Environment, Royal Institute of Technology Stockholm. pp.23-40.

FAO, 2001a. Global Forest Resources Assessment 2000: Main Report. Food and Agriculture Organisation Forestry Paper 140, Rome.

FAO. 2001b. Non-forest Tree Plantations. Report based on the work of W. Killmann. Forest Plantation Thematic Papers. Forest Resources Development Service, Forest Resources Division, FAO, Rome (unpublished).

Forlemu, F., 2013. An Analysis of Co-Management on the Development and Preservation of Natural Resources on the Mount Cameroon National Park. Internship Report. FASA, University of Dschang. 56p.

Melle, E. M., Nakogho, J. A., 2015. The evaluation of rainforest management policies in Idenau Sub-Division, Southwest Region, Cameroon. Department of Environmental Science, University of Buea (unpublished). pp.24-25.

Myers, N., 1992. The Primary Source: Tropical Forests and Our Future. Norton, New York.

Myers, N., 1994. Tropical deforestation: rates and patterns. In: The Causes of Tropical of Tropical Deforestation. The Economic and Statistical Analysis of Factors Giving Rise to the Loss of the Tropical Forest (Eds.: Brown, K., Pearce, D.). UCL Press, pp 27-40.

Putz, F.E., Blate, G.M., Redford, K.H., Fimbel, R., Robinson, J., 2001. Tropical forest management and conservation of biodiversity: An overview. Conserv. Biol. 15, 7-20.

Tako-Tanyi, C., 1999. Sustainable Wildlife Management, West Coast Area of Mount Cameroon. Project Limbe. pp.45-60.

\section{How to cite this article:}

Melle, E. M., Nkwatoh, A. F., Terence, N. H., Achiri, A. B., 2016. The conservation and management challenges of the rainforest of Idenau in Mount Cameroon National Park, Southwest Region, Cameroon. Int. J.

Curr. Res. Biosci. Plant Biol. 3(8), 45-52. doi: http://dx.doi.org/10.20546/ijcrbp.2016.308.007 